Review Article

\title{
Epidemiology, Predisposing Factors, Biomarkers, and Prevention Mechanism of Obesity: A Systematic Review
}

\author{
Melese Linger Endalifer (iD) and Gedefaw Diress $(1)$ \\ College of Health Sciences, Woldia University, Woldia, Ethiopia \\ Correspondence should be addressed to Melese Linger Endalifer; melselinger@gmail.com
}

Received 19 February 2020; Revised 4 May 2020; Accepted 12 May 2020; Published 31 May 2020

Academic Editor: Claire Stocker

Copyright ( $\odot 2020$ Melese Linger Endalifer and Gedefaw Diress. This is an open access article distributed under the Creative Commons Attribution License, which permits unrestricted use, distribution, and reproduction in any medium, provided the original work is properly cited.

Background. Globally, obesity is becoming a public health problem in the general population. Various determinants were reported by different scholars even though there are inconsistencies. Different biomarkers of obesity were identified for the prediction of obesity. Even though researchers speculate the factors, biomarkers, consequences, and prevention mechanisms, there is a lack of aggregate and purified data in the area of obesity. Summary. In this review, the epidemiology, predisposing factors, biomarkers, consequences, and prevention approaches of obesity were reviewed. Key Messages. The epidemiology of obesity increased in low-, middle-, and high-income countries. Even if the factors vary across regions and socioeconomic levels, sociodemographic, behavioral, and genetic factors were prominent for the development of obesity. There are a lot of biomarkers for obesity, of which microRNA, adipocytes, oxidative stress, blood cell profile, nutrients, and microbiota were promising biomarkers for determination of occurrence of obesity. Since the consequences of obesity are vast and interrelated, multidimensional prevention strategy is mandatory in all nations.

\section{Introduction}

The 2017 global nutrition report showed that 2 billion adults are overweight/obese and 41 million children are overweight worldwide [1]. In the last three decades, obesity increased globally; unexpectedly, it is also rising in low- and middleincome countries due to uncontrolled urbanization and nutrition transition (shifting dietary habit from traditional to westernized diet) $[2,3]$. The global prevalence of overweight in children aged less than five years was increased modestly. The trend of overweight was heterogeneous in low- and middle-income countries. Meanwhile, the prevalence of obesity in children aged 2-4 years has increased moderately. In 1975, children with obesity aged 5-19 years were relatively rare, but it becomes highly prevalent in 2016 [4].

In the majority of European countries, the prevalence was increased from $10 \%$ to $40 \%$ in the last 10 years, and specifically in England, it increased more than threefolds [5].

The prevalence of obesity among reproductive-age women was $5.1 \%$ in India [6], $15.7 \%$ in Palestinian schoolchildren, and $34.8 \%$ among adult populations of Saudi Arabia [7]. The prevalence of overweight and obesity was $40.9 \%$ in Kuwait among children aged $6-8$ years. Amazingly, their mothers' perceive that they had healthy weight; in contrary, those children who have normal weight were also criticized by their mothers to be unhealthy [8]

A systematic review conducted in Africa among primary school educators revealed that the continental figure of obesity increased. In this review, the magnitude of obesity was measured based on three international standards, i.e., World Health Organization (WHO), Center for Disease Control (CDC), and International Obesity Taskforce (IOTF) cutoff points. Based on the criteria mentioned above, the prevalence of obesity was $6.1 \%$ (WHO criteria), $4.0 \%$ (IOTF criteria), and $6.9 \%$ (CDC criteria) [9]. Generally, the prevalence of obesity in Africa among schoolchildren lies between $4.4 \%$ and 21.2 percent [9-11].

Another critical issue is currently the emerging sarcopenic obesity. Sarcopenic obesity is defined as loss of skeletal muscle and excess body fat accumulation. Clinically, it can 
be diagnosed through muscle biopsy, computed tomography or magnetic resonance spectroscopy, bioelectrical impedance analysis (BIA), and dual energy X-ray. Primarily, the consequence of sacopenic obesity end is liver cell damage either carcinogen or any abnormality [12]. It is highly prevalent in elder population even though it did not get emphasis in the majority of countries.

\section{Predisposing Factors of Obesity}

Different scholars mention a lot of predisposing factors which vary depending on geography, social conditions, political and economic factors, and human genetics. In aggregate, the commonest factors were sociodemographic, behavioral, genetic, and living in obesogenic environment.

2.1. Sociodemographic Factors. Based on United Nations Children's Fund (UNICEF) causes of malnutrition analysis, three causes were identified. According to the framework, the basic causes including poverty, social condition, and political, economic, ecological, and other factors were the root reason for any form of malnutrition [13]. Different literature studies explicitly identified sociodemographic factors that were highly correlated with obesity, for example, older age [2, 6], married (marital status) [14], low wealth index $[6,10,15-17]$, urban residency $[6,10,16,18]$, being female $[2,9]$, learning in private schools $[2,9,19,20]$, easy accessibility of junk and fired or energy-dense foods and packed animal source foods due to free trade policy [2], rural to urban migration, replacement of local agribusiness with food retail [21], higher education level $[6,7,22]$, and being pregnant $[6,18]$. In contrary to the previous findings, a study conducted among French women shows that having a higher income, a higher occupational class, and a higher educational level and having hot water at home reduce the occurrence of obesity [23] although the pathophysiology of hot water at home and obesity occurrence was not yet studied.

Another cause of obesity mostly in developing countries is that early-life undernutrition leads to later-life obesity and metabolic disorders. The correlation between childhood under nutrition and the development of obesity in later life is idiopathic; but there is a different hypothesis stated by the scholars. Of those, the first is when there is an improvement in the socioeconomic level, and living standards and exposure to obesogenic environments outside the uterus leads to obesity. This might be imbalance between intrauterine and later life nutrient requirements. Secondly, the positive response of under nutrition in the womb to protect vital organs and the exposure to obesogenic environment may leads to obesity. Additionally, the positive response of undernutrition in the womb to protect vital organs and the exposure to obesogenic environment may lead to obesity [2].

2.2. Behavioral Factors (Feeding Habit and Life Style). Nutritionists always use the following proverb to explain the effect of diet in our health "what you eat today; they determine your life tomorrow." Dietary habit is a major determinant factor for our health, not merely to obesity.
Scientifically, consuming energy-dense food, like confectionaries, sugars, soft drinks, fats, and alcohol, were highly correlated with obesity and chronic diseases $[11,24,25]$. Different scholars mentioned that feeding habit culture [26], consuming pastry foods [26], consuming ultraprocessed food (refined carbohydrate) [21], excess alcohol consumption $[10,14]$, and monotonous diet or poor diet quality $[11,24,27,28]$ increase the occurrence of obesity. Eating breakfast and fruit reduces the occurrence of obesity [27], and in other words, evening snack induces obesity [29]. Furthermore, food store environment and school food environment [15] for school age children expose to obesity.

Many literature studies extensively identified that either irregular physical exercise or physical inactiveness $[7,10,14,15,26,30]$, watching television or prolonged screen time $[27,30]$, short sleep duration or shift work $[15,24,30]$, stress, obesogenic environment (urbanization and industrialization) [31], smoking [10], and frequent use of a taxi for transportation [10,32] were determinant factors for overweight/obesity.

Watching electronic screens for more than 2 hours increases the development of obesity because during simple observation, the brain does not utilize glucose and as a result, the metabolism of carbohydrate to glycogen and fat increased consistently [27, 30]. The correlation between stress and the development of obesity has different scientific perspectives. Most scholars conclude that hormonal variation may be a cause. During stress, the cortisol levels rise which is a cause for excess production of abdominal fat by increasing appetite (daily intake) [33-35].

2.2.1. Genetic Factors. Evidence revealed that a family history of obesity and different genetically arranged genes were a risk for obesity $[15,26]$. Genome-wide association studies (GWAS) identified that more than 250 genes/loci were associated with obesity. Of these genes, the fat mass- and obesity-associated gene (FTO) showed an important role for development of the obesity and type 2 diabetes. A study conducted among adults explicitly recognizes the correlation between these genes and a higher body mass index (BMI), fat mass index (FMI), and leptin concentrations [32, 36-38]. Almost all studies included in this review use cross-sectional study design, and majority of those studies assess obesity with the WHO standard (Table 1).

\section{Assessment Methods of Obesity}

In nutritional science, there are four basic nutritional assessment methods, i.e., anthropometric, biochemical, clinical, and dietary methods [42]. Similarly, we can also assess obesity through these methods. In this review, we discuss two nutritional assessment methods (anthropometric and biochemical) in detail.

3.1. Anthropometric Assessment. Obesity can be assessed through BMI, waist circumference (WC), body fat percentage (BFP), and skin fold thickness (SFT). As evidenced in the literature, the anthropometric method shows a 
TABLe 1: Descriptive characteristics of studies included in this review.

\begin{tabular}{|c|c|c|c|c|c|c|}
\hline Authors, country & $\begin{array}{l}\text { Study population } \\
\text { (sample size) }\end{array}$ & Study design & $\begin{array}{c}\text { Anthropometric } \\
\text { used }\end{array}$ & Criteria & $\begin{array}{l}\text { Prevalence } \\
\text { of obesity }\end{array}$ & Risk factors \\
\hline $\begin{array}{l}\text { Al-Lahham et al. } \\
\text { [18], Palestine }\end{array}$ & $\begin{array}{l}\text { Schoolchildren } \\
\qquad(N=1320)\end{array}$ & Cross-sectional & BMI percentiles & $\mathrm{CDC}$ & $15.7 \%$ & $\begin{array}{c}\text { Urban residence and high waist } \\
\text { circumferences }\end{array}$ \\
\hline $\begin{array}{l}\text { Golshevsky et al. } \\
\text { [30], Australia }\end{array}$ & $\begin{array}{l}\text { Children } \\
(N=343)\end{array}$ & Cross-sectional & BMI percentiles & $\mathrm{CDC}$ & $\begin{array}{l}\text { No } \\
\text { prevalence }\end{array}$ & $\begin{array}{c}\text { Watching television, obstructive } \\
\text { sleep and sleep apnea }\end{array}$ \\
\hline $\begin{array}{l}\text { Gokosmanoglu } \\
\text { et al. [26], Turkey }\end{array}$ & $\begin{array}{l}\text { Adolescent } \\
(N=750)\end{array}$ & Cross-sectional & BMI & WHO & $4 \%$ & $\begin{array}{l}\text { Irregular physical exercise, family } \\
\text { history of obesity and consuming } \\
\text { pastry foods }\end{array}$ \\
\hline $\begin{array}{l}\text { Chomba et al. [39], } \\
\text { Tanzania }\end{array}$ & $\begin{array}{l}\text { Schoolchildren } \\
\qquad(N=451)\end{array}$ & Cross-sectional & BMI percentile & WHO & $12.6 \%$ & $\begin{array}{l}\text { Being a girl, random sleeping } \\
\text { time and random eating habit }\end{array}$ \\
\hline $\begin{array}{l}\text { Baratin et al. [40], } \\
\text { Ghanaians }\end{array}$ & Adults $(N=5898)$ & Cross-sectional & BMI & WHO & $\begin{array}{l}\text { No } \\
\text { prevalence }\end{array}$ & $\begin{array}{c}\text { Negative life events and stress at } \\
\text { work place }\end{array}$ \\
\hline $\begin{array}{l}\text { Baalwa et al. [10], } \\
\text { Uganda }\end{array}$ & Adults $(N=683)$ & Cross-sectional & BMI & WHO & $2.3 \%$ & $\begin{array}{l}\text { Urban residence, alcohol } \\
\text { consumption, smoking, physical } \\
\text { inactiveness, using vehicle for } \\
\text { transport and richness }\end{array}$ \\
\hline $\begin{array}{l}\text { Addo et al. [14], } \\
\text { Ghana }\end{array}$ & Adults $(N=180)$ & Cross-sectional & BMI & WHO & $17.8 \%$ & $\begin{array}{l}\text { Being physically inactive, } \\
\text { consumption of alcohol, being } \\
\text { married, female, older age }\end{array}$ \\
\hline $\begin{array}{l}\text { Karki et al. [41], } \\
\text { Nepal }\end{array}$ & $\begin{array}{l}\text { Schoolchildren } \\
\qquad(N=575)\end{array}$ & Cross sectional & BMI for age-sex & WHO & $7.1 \%$ & $\begin{array}{l}\text { Children mothers' high education } \\
\text { level, having professional mother, } \\
\text { consuming energy-dense food, } \\
\text { having sedentary behaviors }\end{array}$ \\
\hline $\begin{array}{l}\text { Ganle et al. [11], } \\
\text { Ghana }\end{array}$ & $\begin{array}{l}\text { School children } \\
\qquad(N=285)\end{array}$ & Cross-sectional & BMI & WHO & $21.2 \%$ & $\begin{array}{l}\text { Being aged } 11-16 \text {, family high } \\
\text { education level and consumption } \\
\text { of fizzy drinks }\end{array}$ \\
\hline $\begin{array}{l}\text { Firouzbakht et al. } \\
\text { [17], Iran }\end{array}$ & Female $(N=680)$ & Cross-sectional & BMI & WHO & $51.2 \%$ & Weak structural social capital \\
\hline $\begin{array}{l}\text { Adom et al. [9], } \\
\text { Africa }\end{array}$ & $\begin{array}{l}\text { Children } \\
(N=89468)\end{array}$ & $\begin{array}{l}\text { Systematic } \\
\text { review and } \\
\text { meta-analysis }\end{array}$ & & $\begin{array}{l}\text { WHO/ } \\
\mathrm{CDC/} \\
\text { IOTF }\end{array}$ & $\begin{array}{c}6.1 \%, 6.9 \% \\
4 \%\end{array}$ & $\begin{array}{l}\text { Urban residence and learning in } \\
\text { private school }\end{array}$ \\
\hline $\begin{array}{l}\text { Al Kibria et al. [6], } \\
\text { India }\end{array}$ & $\begin{array}{c}\text { Women }(N=647 \\
168)\end{array}$ & Cross-sectional & BMI & WHO & $5.1 \%$ & $\begin{array}{l}\text { Older age, ever-pregnant, ever } \\
\text { married, being muslims, high } \\
\text { education level, wealthy and } \\
\text { urban residence }\end{array}$ \\
\hline $\begin{array}{l}\text { Al-Raddadi et al. } \\
\text { [7], Saudi Arabia }\end{array}$ & Adult $(N=1419)$ & Cross-sectional & BMI & WHO & $34.8 \%$ & No factor identified \\
\hline Narciso et al. [15] & Adolescent $(N=)$ & $\begin{array}{l}\text { Systematic } \\
\text { review }\end{array}$ & & & & $\begin{array}{l}\text { Genetic factors and } \\
\text { socioeconomic factors }\end{array}$ \\
\hline $\begin{array}{l}\text { Sagbo et al. [27], } \\
\text { Togo }\end{array}$ & $\begin{array}{l}\text { Adolescent } \\
(N=634)\end{array}$ & Cross-sectional & BMI & IOTF & $1.9 \%$ & $\begin{array}{l}\text { Watching television, medium } \\
\text { dietary diversity score }\end{array}$ \\
\hline $\begin{array}{l}\text { Hu et al. [20], } \\
\text { China }\end{array}$ & Adult $(N=15364)$ & Cross-sectional & BMI & WHO & $7.9 \%$ & Urban residence \\
\hline
\end{tabular}

correlation between the factors $[18,20,43]$. Recently, the classification of obesity was reevaluated and validated again with the consideration of morbidity and mortality at population level. Obesity is further classified into four categories: (1) normal weight obese (NWO), (2) metabolically obese normal weight (MONW), (3) metabolically healthy obese (MHO), and (4) metabolically unhealthy obese (MUO) [44]. The current approach is more reliable than the previous approach to predict obesity and its correlated disorders since using only BMI gives gross data which are difficult to interpret (Table 2).

3.1.1. Biochemical Methods. Among the nutrition assessment methods, the biochemical method is objective and more reliable. There are two types of biochemical methods, functional and static methods. The functional method is used when there is a deficiency or an excess of nutrient which leads to functional impairment [42]. Unexpectedly, obese children have significantly lower ability to identify taste types and qualities correctly due to lesser number of fungiform papillae in the tongue [50].

\section{Biomarkers}

Biomarkers are biological indicators for certain disorders in our body. Different categories of biomarkers were reported globally. Among those, the commonly and widely implemented ones are microRNAs, inflammatory biomarkers, adipocytokines, oxidative stress, gut microbiotas, level of nutrients, and blood cell profiles. 
TABLE 2: Phenotype of obesity and its biomarkers.

\begin{tabular}{|c|c|c|c|}
\hline Type of obesity & Benchmarks & Biomarkers & References \\
\hline Normal weight obese (NWO) & $\begin{array}{l}\text { (A) BMI }=18.5-25 \text { (normal weight) } \\
\text { (B) Higher fasting glucose level } \\
\text { (C) Did not have metabolic } \\
\text { syndrome } \\
\text { (D) High body fat percentage } \\
\checkmark \text { Men-23.5\% } \\
\checkmark \text { Women-29.2\% }\end{array}$ & Proinflammatory cytokines & [44-47] \\
\hline $\begin{array}{l}\text { Metabolically obese normal weight } \\
\text { (MONW) }\end{array}$ & $\begin{array}{l}\text { (A) BMI = 18.5-25 (normal weight) } \\
\text { (B) High body fat percentage }>30 \\
\text { (C) Low insulin sensitivity/ } \\
\text { hyperinsulinemia } \\
\text { (D) Metabolic syndrome happen }\end{array}$ & $\begin{array}{l}\text { Presence of steatosis, concentrations } \\
\text { of high-density cholesterol, triglycerides, } \\
\text { and inflammation biomarkers }\end{array}$ & {$[44-46,48]$} \\
\hline $\begin{array}{l}\text { Metabolically healthy obese } \\
\text { (MHO) }\end{array}$ & $\begin{array}{l}\text { (A) BMI }>30 \text { (obese) } \\
\text { (B) High body fat percentage }>30 \\
\text { (C) Proper sensitivity of insulin }\end{array}$ & $\begin{array}{l}\text { Elevated high sensitivity C-reactive protein } \\
\text { (hs-CRP) and TG }\end{array}$ & {$[44,45,48,49]$} \\
\hline $\begin{array}{l}\text { Metabolically unhealthy obese } \\
\text { (MUO) }\end{array}$ & $\begin{array}{l}\text { (A) BMI }>30 \text { (obese) } \\
\text { (B) High body fat percentage }>30 \\
\text { (C) Insulin resistant, diabetes } \\
\text { mellitus }\end{array}$ & $\begin{array}{l}\text { Higher TG, FBG, TG/HDL-C levels, and lower } \\
\text { levels of HDL }\end{array}$ & {$[44,45,49]$} \\
\hline
\end{tabular}

FBG: fasting glucose; TG: triglyceride; HDL: high-density lipoprotein.

4.1. Micro-RNAs. A study conducted among children identified four miRNAs overexpressed in patients with obesity (miR-222, miR-142-3, miR-140-5p, and miR-143) and two miRNAs (miR-122 and miR-34a) overexpressed in children with obesity and nonalcoholic fatty liver disease (NAFLD) and/or insulin resistance. Circulating miRNAs are promising diagnostic biomarkers of obesity and other disorders such as cardiovascular diseases [51]. Another study also reports eight miRNAs which are found in obese population, that is, PTEN gene (hsa-miR-130b-3p, hsa-miR-142-5p, hsa-miR-148a-3p, hsa-miR-21-5p, hsa-miR23a-3p, hsa-miR-26b-5p, hsa-miR$320 a$, and hsa-miR-486-5p) $[46,47,52]$. The early detection of changes in circulating miRNA levels represents a promising strategy for characterizing obesity and to adjust diet. Moreover, the presence of biomarkers at the early stage is usually associated with metabolic disease or syndrome. As a result, identification of these miRNA is a good strategy for the diagnostic approach as well as to prevent the occurrences [36].

4.2. Inflammatory Biomarkers. Researchers depict that inflammatory biomarkers (C-reactive protein, interleukin-6, and tumor necrosis factor) were identified in obese population $[46,47]$.

4.3. Adipocytokines. Adipocytokines can play a role in the observed link between obesity and its associated morbidities. It has high predictive potential for identification of adverse cardiovascular conditions. Similarly, Plasminogen Activator Inhibitor-1 (PAI-1) was found as an independent risk factor for obesity-related metabolic disorders, even though it needs further investigation on mechanisms of action [53]. Other reviews also suggest that adiponectin, omentin, apelin, leptin, resistin, and fatty-acid-binding protein-4 were promising biomarkers for obesity [46, 47].
4.4. Oxidative Stress. High oxidative stress in the body is usually associated with high anthropometric measurement results, specifically BMI and waist-hip ratio [47, 53]. Among various antioxidants, F2 isoprostanes are widely used to assess lipid oxidation and have demonstrated their ability to predict biological changes and cardiovascular diseases resulting from obesity even though the specificity and sensitivity are not determined. Also, glutathione peroxidase has strong antioxidant and antiatherosclerotic properties. Additionally, complement factor 3 and Monocyte Chemoattractant Protein-1 (MCP-1) promote fat deposition and are also associated with atherosclerosis, excess fat accumulation, and adverse cardiovascular risk [53].

4.5. Gut Microbiota. Helicobacter pylori is an indicator for development of obesity; even though the exact pathophysiology is unknown, most studies correlate with gastrointestinal hormones such as leptin and ghrelin. In normal physiology, ghrelin facilitates food intake and leptin is involved in reduction of food consumption. It is evidenced that there is low serum leptin and ghrelin levels in H. pyloripositive patients. As a result of the level of leptin, food intake will be reduced. So its reduction may be involved in excessive dietary intake and obesity. In contrary, reduction of plasma ghrelin concentration ends with a physiological adaptation to the positive energy balance associated with obesity $[47,54]$.

4.6. Blood Cell Profile. The morbid obesity group had significantly higher platelet counts, plateletcrit (PCT) values, and platelet-to-lymphocyte ratio (PLR) values. The values of white blood cell count and red cell distribution width (RDW) were higher and statistically significant in the obese population [55]. 
4.7. Nutrients. High availability of branched-chain amino acids (BCAA), nonesterified fatty acids, organic acids, acylcarnitines, deficient $25(\mathrm{OH})$ vitamin $\mathrm{D}$ serum concentrations, and phospholipids was identified as potential biomarkers for obesity [56, 57].

\section{Health Impact of Obesity}

High BMI and accumulation of body fat mass are an important predictor for metabolic disorders [43]. Obesity during pregnancy leads to adverse neonatal outcomes (skeletal muscle injury, respiratory distress syndrome, injury to peripheral nervous system, bacterial sepsis, convulsion, hypoglycemia). Additionally, it increases the rate of cesarean section [58-60] and morbidity for the women [61].

Obesity is also associated with a range of comorbidities, including diabetes mellitus [7], dyslipidemia [7], hypertension [7], cardiovascular disease, obstructive sleep apnea, chronic obstructive pulmonary diseases [62], cancer $[63,64]$, chronic disease morbidity and mortality, premature death $[24,62]$, and atrial fibrillation [65]. Hypertension was also strongly associated WC, BMI, and waist hip ratio (WHR) [66].

A review conducted in the USA population shows that the magnitude of obesity among coronary heart disease patients was increased [31]. The effect of obesity varies in different age groups; a systematic review identified that students with obesity in tertiary education have low academic performance and poor achievements either due to weight gain bias stigma or metabolic disorder [67]. A 25year longitudinal study from 1986 to 2011 conducted in America showed that baseline obesity better predicts long-term risk of cerebrovascular death in black individuals as compared to white people. More research should explore factors that explain why racial differences exist in the effects of obesity on cerebrovascular outcome. Findings also have implications for personalized medicine [4].

As indicated from another systematic review, obesity may influence the course of renal cell carcinoma (RCC) patients, although the interplay between obesity and RCC warrants a large prospective confirmation [68].

Central obesity is highly correlated with kidney injury $[62,69]$. It also has significant correlation with urinary incontinency. Specifically, central obesity correlates with intra-abdominal pressure, which exerts forces in the pelvic floor. Polycystic ovary syndrome (POS) was highly correlated with obesity which is highlighted in different clinical and epidemiological studies [70].

Obesity also leads to anatomical deformity; a study conducted in Egypt among schoolchildren explicitly shows that the occurrence of flat foot was high among obese children. The presence of flat foot leads to foot pain which is significantly manifested with increased level of adipocyte cytokines, as well as adiponectin, leptin, resistin, Il-6, and TNF- $\alpha$, compared to subjects with normal BMI [71]. Physical inactiveness like slow waking/decreased velocities $[72,73]$ and mental comorbidities [72] were also other consequences of obesity.
Amazingly, obesity has significant effect on the reproduction of human. Sexual dysfunction is highly prevalent in men with severe with erectile dysfunction in diabetic patients was likely a significant contributing factor for sexual dysfunction in obese population [74-76].

Obesity leads to development of different cancers; this is why, cancer epidemiology abruptly increased worldwide. Obesity also promotes breast cancer formation [77] and formation of Barrett's esophagus (BE) [78]. BE has been defined as a pathological state in which the stratified squamous epithelium of the distal esophagus has been replaced by the metaplastic columnar epithelium with goblet cells. The formation of $\mathrm{BE}$ predisposes patients to esophageal adenocarcinoma (EAC) [78].

The impact of obesity varies based on the trait and biological differences like sex. Also, it has an etiological role in the death of most people globally [62]. In general, the public health significance of obesity is highly integrated with country's economic, social, and political affairs.

\section{Prevention and Treatment Mechanism}

Obesity is a disorder which occurs due to individual behaviors and the living environment. As a result of this, to prevent obesity, both legal and voluntary counseling services are mandatory. Obesity can be prevented or treated based on the following approach.

6.1. Nutrition Education. Nutrition education is one of the common legal approaches practiced at schools to reduce obesity in the USA. Disseminating health education and developing dietary consumption standards at organization level also have significant impact [79]; weight loss programs [70] and diabetes prevention approaches were effective programs to reduce obesity which is reported elsewhere [80]. Interventional studies which are entitled as "Healthy Primary School of the Future" implemented in Dutch are primarily focused on lunch health education, healthy diet approach, and physical activity session, lowering children's BMI z-scores [82]. Another program conducted in Brooklyn entitled as "Live Light Live Right program" is a life style intervention that uses medical assessment, nutritional education, access to physical fitness classes, and behavioral modification to reduce BMI Z-Scores [83]. Even moderate physical activity is effective to control overweight/obesity among pregnant women $[83,84]$.

6.2. Developing Nonsedentary Life Style Plan. Physical activity, reducing sedentary time, reducing fast food consumption, sleeping 7-9 hours per day, avoiding smoking, and moderate alcohol drinking habit were effective interventions to reduce obesity [85].

6.3. Healthy Food Subsidization and Taxation of Junk Food. The good news regarding obesity is that the government can reduce obesity by subsidization of healthy foods or 
increasing taxation of junk foods. This is strongly implemented in the UK; this scenario shows that an increment of price of high sugar snacks by $20 \%$ shows significant reduction in energy intake, BMI, and prevalence of obesity. As a result, increasing taxation or price for unhealthy foods is an effective approach to control obesity and their metabolic disorder [86].

6.4. Surgery. Metabolic and bariatric surgery in the pediatric population provides evidence-based effective treatment of severe obesity and related comorbid diseases in the USA [87].

\section{Conclusion and Future Perspectives}

Obesity is becoming a severe public health problem; its epidemiology is increasing rapidly. The exposure factors vary across different geopolitics. Primarily, living in obesogenic environments such as sedentary life style, urbanization, and rural to urban migration, consuming energydense foods, and physical inactivity were determinants. There are a lot of biomarkers, of which microRNAs, adipocytes, oxidative stress, and microbiota were promising for determination of obesity. Since the consequences of obesity are vast and interrelated, a multilevel prevention strategy is mandatory. For future researchers, the sensitivity of the anthropometric measurement tool was not studied. So it is better to study sensitivity and its correlation with the best promising biomarkers since they reduce health cost and facilitate early identification of obesity.

\section{Conflicts of Interest}

The authors declare that there are no conflicts of interest.

\section{References}

[1] Development Initiative, Global Nutrition Report 2017: Nourishing the SDGs, Development Initiatives, Bristol, UK, 2017.

[2] N. D. Ford, S. A. Patel, and K. M. V. Narayan, "Obesity in lowand middle-income countries: burden, drivers, and emerging challenges," Annual Review of Public Health, vol. 38, no. 1, pp. 145-164, 2017.

[3] D. J. Hoffman, Obesity in Developing Countries: Causes and Implications, Rutgers University, New Brunswick, NY, USA, 2001.

[4] S. Assari and M. Bazargan, "Baseline obesity increases 25-year risk of mortality due to cerebrovascular disease: role of race," International Journal of Environmental Research and Public Health, vol. 16, no. 19, p. 3705, 2019.

[5] M. Agha and R. Agha, "The rising prevalence of obesity: part a-impact on public health," International Journal of Surgery Oncology, vol. 2, no. 7, p. e17, 2017.

[6] G. M. Al Kibria, K. Swasey, M. Z. Hasan, A. Sharmeen, and B. Day, "Prevalence and factors associated with underweight, overweight and obesity among women of reproductive age in India," Global Health Research Policy, vol. 4, no. 1, p. 24, 2019.

[7] R. Al-Raddadi, A. U. Bahijri, H. A. Jambi, G. Ferns, and J. Tuomilehto, "The prevalence of obesity and overweight, associated demographic and lifestyle factors, and health status in the adult population of Jeddah, Saudi Arabia," Therapeutic Advances in Chronic Disease, vol. 10, 2019.

[8] Y. AlRodhan, Y. AlAbdeen, E. Saleh et al., "Obesity and maternal perception: a cross-sectional study of children aged 6 to 8 years in Kuwait," Eastern Mediterranean Health Journal, vol. 25, no. 7, pp. 465-472, 2019.

[9] T. Adom, A. P. Kengne, A. De Villiers, and T. Puoane, "Prevalence of overweight and obesity among African primary school learners: a systematic review and meta-analysis," Obesity Science \& Practice, vol. 5, no. 5, pp. 487-502, 2019.

[10] J. Baalwa, B. B. Byarugaba, E. K. Kabagambe, and A. M Otim, "Prevalence of overweight and obesity in young adults in Uganda," African Health Sciences, vol. 10, no. 4, pp. 367-373, 2010.

[11] J. K. Ganle, P. P. Boakye, and L. Baatiema, "Childhood obesity in urban Ghana: evidence from a cross-sectional survey of inschool children aged 5-16 years," BMC Public Health, vol. 19, no. 1, p. 1561, 2019.

[12] G. Baffy, "Sarcopenic obesity in liver cancer: it is SO complicated," HepatoBiliary Surgery and Nutrition, vol. 8, no. 5, pp. 560-562, 2019.

[13] United Nations Children's Fund, Strategy for Improved Nutrition of Children and Women in Developing Countries UNICEF, United Nations Children's Fund, New York, NY, USA, 1990.

[14] P. N. O. Addo, K. M. Nyarko, S. O. Sackey, P. Akweongo, and B. Sarfo, "Prevalence of obesity and overweight and associated factors among financial institution workers in Accra Metropolis, Ghana: a cross sectional study," BMC Research Notes, vol. 8, no. 1, 2015.

[15] J. Narciso, A. J. Silva, V. Rodrigues et al., "Behavioral, contextual and biological factors associated with obesity during adolescence: a systematic review," PLoS One, vol. 14, no. 4, Article ID e0214941, 2019.

[16] P. C. d. Santos, K. S. d. Silva, J. A. d. Silva et al., "Change in overweight and obesity over a decade according to sociodemographic factors in Brazilian adolescents," Ciência \& Saúde Coletiva, vol. 24, no. 9, pp. 3335-3344, 2019.

[17] M. Firouzbakht, M. E. Riahi, M. Hajian-Tilaki et al., "Relationship of social capital with overweight and obesity among female health care workers," Caspian Journal of Internal Medicine, vol. 10, no. 3, pp. 281-288, 2019.

[18] S. Al-Lahham, N. Jaradat, M. Altamimi et al., "Prevalence of underweight, overweight and obesity among Palestinian school-age children and the associated risk factors: a cross sectional study," BMC Pediatrics, vol. 19, no. 1, p. 483, 2019.

[19] I. J. Na, "Proceedings of the Bjorntorp Symposium on Stress, Obesity, and Metabolic Syndrome, a satellite symposium to the 39th Annual Scientific Meeting of the European Society of Clinical Investigation. April 9-10, 2005. Athens, Greece," Annals of the New York Academy of Sciences, vol. 1083, pp. 1-344, 2006.

[20] L. Hu, X. Huang, C. You et al., "Prevalence of overweight, obesity, abdominal obesity and obesity-related risk factors in southern China," PLoS One, vol. 12, no. 9, Article ID e0183934, 2017.

[21] B. M. Popkin, C. Corvalan, and L. M. Grummer-Strawn, "Dynamics of the double burden of malnutrition and the changing nutrition reality," The Lancet, vol. 395, no. 10217, pp. 65-74, 2020.

[22] H. Y. Berhane, M. Jirström, S. Abdelmenan et al., "Social stratification, diet diversity and malnutrition among preschoolers: a survey of Addis Ababa, Ethiopia," Nutrients, vol. 12, no. 3, p. 712, 2020. 
[23] A. Auguste, D. Julien, M. Gwenn, C. Barul, J.-B. Richard, and D. Luce, "Social distribution of tobacco smoking, alcohol drinking and obesity in the French West Indies," BMC Public Health, vol. 19, no. 1, p. 1424, 2019.

[24] A. Hruby, J. E. Manson, L. Qi et al., "Determinants and consequences of obesity," American Journal of Public Health, vol. 106, no. 9, pp. 1656-1662, 2016.

[25] S. J. Yoon, H. J. Kim, and M. Doo, "Association between perceived stress, alcohol consumption levels and obesity in Koreans," Asia Pacific Journal of Clinical Nutrition, vol. 25, no. 2, pp. 316-325, 2016.

[26] F. Gokosmanoglu, H. Cengiz, C. Varim, S. Yaylaci, A. Nalbant, and C. Karacaer, "The prevalence of obesity and the factors affecting obesity in the students of secondary education," International Journal of Research in Medical Sciences, vol. 7, no. 8, pp. 2989-2994, 2019.

[27] H. Sagbo, D. K. Ekouevi, D. T. Ranjandriarison et al., "Prevalence and factors associated with overweight and obesity among children from primary schools in urban areas of Lomé, Togo," Public Health Nutrition, vol. 21, no. 6, pp. 1048-1056, 2018.

[28] C. Ngaruiya, A. Hayward, L. Post, and H. Mowafi, "Obesity as a form of malnutrition: over-nutrition on the Uganda "malnutrition" agenda," Pan African Medical Journal, vol. 28, no. 49, 2017.

[29] W. E. Barrington and S. A. A. Beresford, "Eating occasions, obesity and related behaviors in working adults: does it matter when you snack?" Nutrients, vol. 11, no. 10, p. 2320, 2019.

[30] D. M. Golshevsky, C. Magnussen, M. Juonala, K.-T. Kao, B. E. Harcourt, and M. A. Sabin, "Time spent watching television impacts on body mass index in youth with obesity, but only in those with shortest sleep duration," Journal of Paediatrics and Child Health, 2019.

[31] C. Andonian, F. Langer, J. Beckmann et al., "Overweight and obesity: an emerging problem in patients with congenital heart disease," Cardiovascular Diagnosis and Therapy, vol. 9, no. S2, pp. S360-S368, 2019.

[32] E. E. Cinteza and M. Cintez, "Biomarkers in obesity," Revista Română de Medicină de Laborator, vol. 26, no. 3, pp. 353-358, 2018.

[33] E. S. van der Valk, M. Savas, and E. F. C. van Rossum, "Stress and obesity: are there more susceptible individuals?" Current Obesity Reports, vol. 7, no. 2, pp. 193-203, 2018.

[34] N. Rasheed, "Stress-associated eating leads to obesity," International Journal of Health Sciences (Qassim), vol. 11, no. 2, pp. 1-2, 2017.

[35] I. Boniecka, H. Wileńska, A. Jeznach-Steinhagen, A. Czerwonogrodzka-Senczyna, M. Sekuła, and K. Paśnik, "Stress as a factor contributing to obesity in patients qualified for bariatric surgery-studies in a selected group of patients (a pilot study)," Videosurgery and Other Miniinvasive Techniques, vol. 1, no. 1, pp. 60-67, 2017.

[36] E. G. Seay, G. Mulholland, and R. C. Dedhia, "Upper airway surgery to rescue the "untitratable" patient with OSA and obesity," Journal of Clinical Sleep Medicine, vol. 16, no. 1, pp. 149-151, 2019.

[37] E. Ferris and C. Gregg, "Parallel accelerated evolution in distant hibernators reveals candidate cis elements and genetic circuits regulating mammalian obesity," Cell Reports, vol. 29, no. 9, pp. 2608.e4-2620.e4, 2019.

[38] H. Choquet and D. Meyre, "Genetics of obesity: what have we learned?” Current Genomics, vol. 12, no. 3, pp. 169-179, 2011.

[39] H. Chomba, H. D. Martin, and J. Kimywe, "Prevalence and predictors of obesity among 7 - to 17-year-old schoolchildren in Urban Arusha, Tanzania," Journal of Nutrition and Metabolism, vol. 2019, Article ID 3106597, 11 pages, 2019.

[40] C. Baratin, E. Beune, D. van Schalkwijk et al., "Differential associations between psychosocial stress and obesity among ghanaians in Europe and in Ghana: findings from the RODAM study," Social Psychiatry and Psychiatric Epidemiology, vol. 55, no. 1, pp. 45-56, 2019.

[41] A. Karki, A. Shrestha, and N. Subedi, "Prevalence and associated factors of childhood overweight/obesity among primary school children in urban nepal," BMC Public Health, vol. 19, no. 1, 2019.

[42] R. S. Gibson, Principle of Nutritional Assessment, Oxford University Press, New York, NY, USA, 2nd edition, 2005.

[43] G. H. Goossens, "The metabolic phenotype in obesity: fat mass, body fat distribution, and adipose tissue function," The European Journal of Obesity, vol. 10, no. 3, pp. 207-215, 2017.

[44] A. D. Lorenzo, "New obesity classification criteria as a tool for bariatric surgery indication," World Journal of Gastroenterology, vol. 22, no. 2, pp. 681-703, 2016.

[45] P. Cembrowska, A. Stefańska, and G. Odrowąż-Sypniewska, "Obesity phenotypes: normal-weight individuals with metabolic disorders versus metabolically healthy obese," Medical Research Journal, vol. 1, no. 3, pp. 95-99, 2017.

[46] K. Aleksandrova, D. Mozaffarian, and T. Pischon, "Addressing the perfect storm: biomarkers in obesity and pathophysiology of cardiometabolic risk," Clinical Chemistry, vol. 64, no. 1, pp. 142-153, 2018.

[47] M. N. Meza and J. A. B. Carrillo, "Biomarkers, obesity, and cardiovascular diseases," Role of Biomarkers in Medicine, Intechopen, London, UK, 2016.

[48] S. Shaharyar, L. R. Lara, J. Omar et al., "Obesity and metabolic phenotypes (metabolically healthy and unhealthy variants) are significantly associated with prevalence of elevated C-reactive protein and hepatic steatosis in a large healthy Brazilian population," Journal of Obesity, vol. 2015, Article ID 178526, 6 pages, 2015.

[49] A. Bakhtiari, K. Hajian-Tilaki, and A. Ghanbarpour, "Metabolic syndrome and different obesity phenotypes in the elderly women population: Iran's Health System on aging," Caspian Journal of Internal Medicine, vol. 9, no. 3, pp. 252-259, 2018.

[50] C. Mameli, C. Cattaneo, S. Panelli et al., "Taste perception and oral microbiota are associated with obesity in children and adolescents," PLoS One, vol. 14, no. 9, Article ID e0221656, 2019.

[51] M. Oses, J. M Sanchez, M. P. Portillo, C. M. Aguilera, and I. Labayen, "Circulating miRNAs as biomarkers of obesity and obesity-associated comorbidities in children and adolescents: a systematic review," Nutrients, vol. 11, no. 12, p. 2890, 2019.

[52] A. Ortiz-Dosal, P. Rodil-García, and L. A. Salazar-Olivo, "Circulating microRNAs in human obesity: a systematic review," Biomarkers, vol. 24, no. 6, pp. 499-509, 2019.

[53] S. Musaad and E. N. Haynes, "Biomarkers of obesity and subsequent cardiovascular events," Epidemiologic Reviews, vol. 29, no. 1, pp. 98-114, 2007.

[54] H. Xue, X. Cheng, P. Jia, and Y. Wang, "Road network intersection density and childhood obesity risk in the US: a national longitudinal study," Public Health, vol. 178, pp. 3137, 2019.

[55] E. Erdal and M. İnanir, "Platelet-to-lymphocyte ratio (PLR) and Plateletcrit (PCT) in young patients with morbid obesity," Revista da Associação Médica Brasileira, vol. 65, no. 9, pp. 1182-1187, 2019.

[56] F. Cembranel, J. P. Wagner, W. C Giehl et al., "Obesity and $25(\mathrm{OH}) \mathrm{D}$ serum concentration are more important than vitamin $\mathrm{D}$ intake for changes in nutritional status indicators: a 
population-based longitudinal study in a state capital city in southern Brazil," Nutrients, vol. 11, no. 10, p. 2366, 2019.

[57] S. Rauschert, O. Uhl, B. Koletzko, and C. Hellmuth, "Metabolomic biomarkers for obesity in humans: a short review," Annals of Nutrition and Metabolism, vol. 64, no. 3-4, pp. 314-324, 2014.

[58] A. Angeliki, P. Dimitrios, and C. Tzavara, "Maternal obesity and its association with the mode of delivery and the neonatal outcome in induced labour: implications for midwifery practice," European Journal of Midwifery, vol. 2, 2018.

[59] O. A. Emmanuel, A. Auta, V. Khanal, S. J. Tapshak, and Y. Zhao, "Cesarean delivery in Nigeria: prevalence and associated factors-a population-based cross-sectional study," BMJ Open, vol. 9, no. 6, Article ID e027273, 2019.

[60] M. Saman, A. Payam, H. Mostafa et al., "Determinants of cesarean section among primiparas: a comparison of classification methods," Iranian Journal of Public Health, vol. 47, no. 12, pp. 1913-1922, 2018.

[61] M. Blomberg, "Maternal obesity, mode of delivery, and neonatal outcome," Obstetrics and Gynecology, vol. 122, no. 1, pp. 50-55, 2013.

[62] J. C. Censin, S. A. E. Peters, J. Bovijn et al., "Causal relationships between obesity and the leading causes of death in women and men," PLoS Genetics, vol. 15, no. 10, Article ID e1008405, 2019.

[63] S. M. Fruh, "Obesity: risk factors, complications, and strategies for sustainable long-term weight management," Journal of the American Association of Nurse Practitioner, vol. 29, pp. S3-S14, 2017.

[64] A. D. Hingorani, C. Finan, and A. F. Schmidt, "Obesity causes cardiovascular diseases: adding to the weight of evidence," European Heart Journal, vol. 41, no. 2, pp. 227-230, 2019.

[65] Z. Almuwaqqat, W. T. O’Neal, F. L. Norby et al., "Joint associations of obesity and NT-proBNP with the incidence of atrial fibrillation in the ARIC study," Journal of the American Heart Association, vol. 8, no. 19, Article ID e013294, 2019.

[66] G. M. D. Chaudhary, A. T. U. Din, F. M. D. Chaudhary et al., "Association of obesity indicators with hypertension in type 2 diabetes mellitus patients," Cureus, vol. 11, no. 7, p. e5050, 2019.

[67] A. J. Hill, R. R. Lopez, and I. D. Caterson, "The relationship between obesity and tertiary education outcomes: a systematic review," International Journal of Obesity, vol. 43, no. 11, pp. 2125-2133, 2018.

[68] G. Aurilio, F. Piva, M. Santoni et al., "The role of obesity in renal cell carcinoma patients: clinical-pathological implications," International Journal of Molecular Sciences, vol. 20, no. 22, p. 5683, 2019.

[69] Y. Cao, G. Sun, R. Liu et al., "Plasma triglyceride levels and central obesity predict the development of kidney injury in Chinese community older adults," Renal Failure, vol. 41, no. 1, pp. 946-953, 2019.

[70] T. M. Barber, H. Petra, O. Martin, and S. Franks, "Obesity and polycystic ovary syndrome: implications for pathogenesis and novel management strategies," Clinical Medicine Insights: Reproductive Health, vol. 13, 2019.

[71] A. H. Alghadir, S. A. Gabr, and A. A. Rizk, "Plasmatic adipocyte biomarkers and foot pain associated with flatfoot in schoolchildren with obesity," Revista da Associação Médica Brasileira, vol. 65, no. 8, pp. 1061-1066, 2019.

[72] Z. C. Skea, M. Aceves-Martins, C. Robertson, M. D. Bruin, and A. Avenell, "Acceptability and feasibility of weight management programmes for adults with severe obesity: a qualitative systematic review," BMJ Open, vol. 9, no. 9, Article ID e029473, 2019.

[73] S. V. Gill, "Effects of obesity class on flat ground walking and obstacle negotiation," Journal of Musculoskeletal Neuronal Interactions, vol. 19, no. 4, pp. 448-454, 2019.

[74] J. H. Ho, S. Adam, S. Azmi et al., "Male sexual dysfunction in obesity: the role of sex hormones and small fibre neuropathy," PLoS One, vol. 14, no. 9, Article ID e0221992, 2019.

[75] V. A. Giagulli, C. Marco, M. Isanna et al., "The role of diet and weight loss in improving secondary hypogonadism in men with obesity with or without type 2 diabetes mellitus," $\mathrm{Nu}$ trients, vol. 11, no. 12, p. 2975, 2019.

[76] C. J. Fernandez, E. C. Chacko, and J. M. Pappachan, "Male obesity-related secondary hypogonadism-pathophysiology, clinical implications and management," European Endocrinology, vol. 15, no. 2, pp. 83-90, 2019.

[77] G. C. M. Evangelista, A. S. Pollyanna, M. A. S. Sara et al., “4T1 mammary carcinoma colonization of metastatic niches is accelerated by obesity," Frontiers in Oncology, vol. 9, p. 685, 2019.

[78] K. A. Dias, J. S. Ramos, M. P. Wallen et al., "Accuracy of longitudinal assessment of visceral adipose tissue by dualenergy X-ray absorptiometry in children with obesity," Journal of Obesity, vol. 2019, 12 pages, Article ID 2193723, 2019.

[79] S. E. Abiola and M. M. Mello, "Multilevel legal approaches to obesity prevention: a conceptual and methodological toolkit," PLoS One, vol. 14, no. 10, Article ID e0220971, 2019.

[80] B. Armenta-Guirado, T. Martínez-Contreras, M. C. CandiaPlata et al., "Effectiveness of the diabetes prevention program for obesity treatment in real world clinical practice in a middle-income country in Latin America," Nutrients, vol. 11, no. 10, p. 2324, 2019.

[81] M. Arora, S. Barquera, N. J. Farpour Lambert et al., "Stigma and obesity: the crux of the matter," The Lancet Public Health, vol. 4, no. 11, pp. e549-e550, 2019.

[82] N. H. M. Bartelink, P. van Assema, S. P. J. Kremers et al., "Can the healthy primary school of the future offer perspective in the ongoing obesity epidemic in young children? A Dutch quasi-experimental study," BMJ Open, vol. 9, no. 10, Article ID e030676, 2019.

[83] N. S. Bayoumi, E. Helzner, A. Afable, M. A. Joseph, and S. Dhuper, "A real-world evaluation of a tertiary care childhood obesity intervention to reduce metabolic risk in a hard-to-reach urban population," BMC Pediatrics, vol. 19, no. 1, p. 378, 2019.

[84] C. Flannery, M. Fredrix, E. K. Olander, F. M. McAuliffe, M. Byrne, and P. M. Kearney, "Effectiveness of physical activity interventions for overweight and obesity during pregnancy: a systematic review of the content of behaviour change interventions," International Journal of Behavioral Nutrition and Physical Activity, vol. 16, no. 1, p. 97, 2019.

[85] D. B. Bookwalter, B. Porter, I. G. Jacobson et al., "Healthy behaviors and incidence of overweight and obesity in military veterans," Annals of Epidemiology, vol. 39, pp. 26-32.e1, 2019.

[86] F. D. Pauline, L. Cornelsen, T. Marteau, S. A. Jebb, and R. D. Smith, "Potential impact on prevalence of obesity in the UK of a $20 \%$ price increase in high sugar snacks: modelling study," BMJ, vol. 10, p. 14786, 2019.

[87] C. F. Bolling, S. C. Armstrong, K. W. Reichard et al., "Metabolic and bariatric surgery for pediatric patients with severe obesity," Pediatrics, vol. 144, no. 6, Article ID e20193224, 2019. 